\title{
SYTUACJA MIESZKANIOWA W POLSCE W LATACH 2007-2013 W KONTEKŚCIE ZMIAN DEMOGRAFICZNYCH
}

\begin{abstract}
Mieszkanie traktowane jest jako dobro podstawowe, którego dostępność warunkuje prawidłowe funkcjonowanie i rozwój rodziny (gospodarstwa domowego). Kwestie związane z posiadaniem, dostępnością i jakością substancji mieszkaniowej są przedmiotem zainteresowania polityki mieszkaniowej. Na politykę mieszkaniową składają się więc wszelkie działania państwa, które mają wpływ na funkcjonowanie i wynik rynku mieszkaniowego, tj. na liczbę, cenę, stawki czynszu oraz jakość mieszkań. Stan zasobów mieszkaniowych w Polsce szacowany jest na 13747 tys. mieszkań (GUS 2013). Aby ocenić zasobność kraju w mieszkania posłużono się wskaźnikiem liczby mieszkań przypadających na 1000 mieszkańców, który w Polsce wynosi 349 i jest jednym z najniższych w Unii Europejskiej. W rządowym dokumencie „Główne problemy, cele $i$ kierunki programu wspierania rozwoju budownictwa mieszkaniowego do 2020 roku" opublikowanym w 2010 roku deficyt mieszkaniowy definiowany jako różnica między liczbą gospodarstw domowych a liczbą mieszkań zamieszkałych oszacowany został na 1,4 - 1,5 mln mieszkań. Szacunki te opierają się jednak na danych Narodowego Spisu Powszechnego z 2002 roku oraz na prognozach statystycznych dotyczących liczby gospodarstw domowych. Jednocześnie w latach 2002-2013 oddano do użytku przeszło 1,6 mln mieszkań. Nie bez znaczenia na wielkość deficytu mieszkaniowego pozostają czynniki demograficzne, w szczególności migracje zarobkowe. Celem artykułu była analiza sytuacji mieszkaniowej oraz skali potrzeb mieszkaniowych w zmieniającej się sytuacji demograficznej. Oceny dokonano na podstawie danych statystycznych (Narodowego Spisu Powszechnego) z 2011 roku, z uwzględnieniem zmian demograficznych w latach 2002-2013.

Słowa kluczowe: mieszkanie, sytuacja mieszkaniowa, potrzeby mieszkaniowe, polityka mieszkaniowa, deficyt mieszkaniowy
\end{abstract}

\section{WSTĘP I CEL BADAŃ}

Rynek mieszkaniowy pełni szczególną rolę na rynku nieruchomości z racji roli, jaką pełni mieszkanie w życiu człowieka. Mieszkanie traktowane jest powszechnie jako dobro

\footnotetext{
${ }^{1}$ Agnieszka Napiórkowska - Baryła, Uniwersytet Warmińsko - Mazurski w Olsztynie, Katedra Ekonomiki Przestrzennej i Środowiskowej, ul. Oczapowskiego 4, 10 - 900 Olsztyn, Tel. (89) 52342-35, agnieszka.baryla@uwm.edu.pl

${ }^{2}$ Mirosława Witkowska- Dąbrowska, Uniwersytet Warmińsko - Mazurski w Olsztynie, Katedra Ekonomiki Przestrzennej i Środowiskowej, ul. Oczapowskiego 4, 10 - 900 Olsztyn, Tel. (89) 52335-48, m.witkowska@uwm.edu.pl

${ }^{3}$ Ilisio Manuel de Jesus Uniwersytet Warmińsko - Mazurski w Olsztynie, Katedra Ekonomiki Przestrzennej i Środowiskowej, ul. Oczapowskiego 4, 10 - 900 Olsztyn, Tel. (89) 523-43-33, imdj@uwm.edu.pl
} 
niezbędne każdej rodzinie (lub gospodarstwu domowemu), umożliwiające jej zaspokojenie potrzeb zarówno podstawowych, jak i potrzeb wyższego rzędu. Brak mieszkania uznaje się za istotne utrudnienie w rozwoju rodziny. Należąc do wąskiego zbioru dóbr podstawowych, mieszkanie jest jednocześnie jednym z najdroższych dóbr. Gospodarstwa domowe uznają posiadanie mieszkania na własność za główny cel życiowy, który starają się systematycznie realizować, ponosząc przez wiele lat wydatki stanowiące istotną część domowych budżetów. Pozostaje jednak znaczna część gospodarstw domowych, która nie jest i nie będzie w stanie samodzielnie zrealizować zakupu mieszkania, zdana na pomoc publiczną w ramach prowadzonej polityki wspierającej obywateli w rozwiązywaniu problemów mieszkaniowych. Konieczność interwencji władz publicznych w tym zakresie nigdy nie była kwestionowana, zmieniały się natomiast cele i formy interwencjonizmu państwowego (ulgi podatkowe, dopłaty do odsetek spłacanych kredytów, budownictwo społeczne). Jednocześnie od początków transformacji w Polsce słyszymy o deficycie mieszkaniowym, definiowanym jako różnica między liczbą gospodarstw domowych a liczbą mieszkań zamieszkałych. Deficyt mieszkaniowy w rządowym dokumencie „Główne problemy, cele i kierunki programu wspierania rozwoju budownictwa mieszkaniowego do 2020 roku"4 opublikowanym w 2010 roku oszacowany został na 1,8 mln mieszkań. Przy uwzględnieniu faktu, że część mieszkań będących w budowie jest już faktycznie zamieszkałych, kolejna część mieszkań teoretycznie niezamieszkałych funkcjonuje w szarej strefie najmu, zmniejsza to deficyt mieszkaniowy do poziomu 1,4 - 1,5 mln mieszkań. Szacunki te opierają się na danych Narodowego Spisu Powszechnego z 2002 roku. Jednocześnie w latach 2002-2013 oddano do użytku przeszło 1,6 mln mieszkań, celowym wydaje się więc ocena skali potrzeb mieszkaniowych w Polsce określanych na podstawie danych statystycznych $\mathrm{z}$ uwzględnieniem zmian demograficznych (liczby gospodarstw domowych) w latach 20022013.

2. PODSTAWOWE ZALOŻENIA POLITYKI MIESZKANIOWEJ I STAN RYNKU MIESZKANIOWEGO

Kwestie związane z posiadaniem, dostępnością i jakością substancji mieszkaniowej są przedmiotem zainteresowania polityki mieszkaniowej, którą A. Andrzejewski ${ }^{5}$ zdefiniował jako ogólny kierunek i metody działania używane przez państwa lub inne podmioty publiczne, organizacje polityczne i społeczne do osiągnięcia określonych celów w dziedzinie mieszkalnictwa oraz zaspokajania potrzeb mieszkaniowych. W znaczeniu naukowym polityka mieszkaniowa określa metody oddziaływania na stosunki mieszkaniowe oraz utrzymywanie i powiększanie zasobu mieszkaniowego stanowiącego podstawę tych stosunków. Definicja sformułowana przez A. Andrzejewskiego pozostaje nadal aktualna, o czym świadczy odwoływanie się do niej przez wielu autorów, którzy jednocześnie zwracają uwagę na konieczność badania i monitorowania (ilości i jakości) zasobów mieszkaniowych oraz określania na tej podstawie potrzeb mieszkaniowych. P. Hut $^{6}$ podaje, że polityka mieszkaniowa to celowe działanie instytucji państwowych i

${ }^{4}$ http://orka.sejm.gov.pl/Druki6ka.nsf/wgdruku/3725/\$file/3725.pdf, dostęp 15.01.2014r.

${ }^{5}$ A. Andrzejewski, Polityka mieszkaniowa, PWE Warszawa 1987, s. 28-31

${ }^{6}$ P.Hut, Współczesna kwestia mieszkaniowa w Polsce; geneza, uwarunkowania, perspektywy rozwiązań W: Polityka społeczna (red) G. Firlit-Fesnak i M. Szylko-Skoczny, Wydawnictwo Naukowe PWN Warszawa 2009, s. 294 
społecznych określone wcześniejszą analizą, za pomocą prawnych i finansowych instrumentów, mające na celu poprawę sytuacji mieszkaniowej. Według L. Frąckiewicz ${ }^{7}$ polityka mieszkaniowa jako dyscyplina badawcza diagnozuje różnice mieszkaniowe, bada całokształt stosunków mieszkaniowych w aspektach: ekonomicznym, społecznym i technicznym. Zajmuje się metodami określania skali potrzeb mieszkaniowych jak również poziomu ich zaspokojenia oraz optymalnego zastosowania środków publicznych, społecznych i indywidualnych. Dotyczy to zarówno tworzenia nowych zasobów mieszkaniowych, jak i procesu ich reprodukcji. Na politykę mieszkaniową składają się więc wszelkie działania państwa, które mają wpływ na funkcjonowanie i wynik rynku mieszkaniowego, tj. na liczbę, cenę, stawki czynszu oraz jakość mieszkań ${ }^{8}$.

W definicjach określających cele i zakres polityki mieszkaniowej pojawia się kwestia dotycząca wyniku mieszkaniowego (liczby mieszkań) jako efektu końcowego prowadzonych działań. Stan zasobów mieszkaniowych w Polsce szacowany jest na 13 747 tys. mieszkań ${ }^{9}$, i jest ściśle związany z liczbą mieszkań corocznie oddawanych do użytku. W tabeli 1 przedstawione zostały wyniki rynku mieszkaniowego - liczba mieszkań nowo wybudowanych z podziałem na inwestorów w latach 2002-2013, które wskazują, że zasób mieszkań w Polsce powiększył się o około 1,6 mln. Każdego roku było oddawanych do użytku średnio około 135 tys. mieszkań (97 595 w 2002 r. - 165189 w 2008 r.).

W badanych latach najwyższy udział w mieszkaniach oddanych do użytku ogółem stanowiły mieszkania indywidualne. Ich udział kształtował się na poziomie $45 \%$ do $72 \%$ wszystkich oddanych do użytku mieszkań. Kolejną kategorią po indywidualnych zajmują mieszkania przeznaczone na sprzedaż (czyli deweloperskie), ich udział w ogólnej strukturze wahał się od $15 \%$ do $45 \%$. W ostatnich latach regres przeżywa budownictwo spółdzielcze, komunalne i społeczne czynszowe. Zjawisko to może świadczyć o niedostatecznej efektywności instrumentów pomocowych ze strony państwa i przede wszystkim samorządów, które mają obowiązek zapewnić lokale najuboższej części społeczeństwa.

Mieszkania spółdzielcze oraz pozostałe (zakładowe, komunalne, społeczne czynszowe) w każdym roku stanowiły niewielki odsetek wszystkich oddanych do użytkowania mieszkań. Udział w nowo wybudowanych lokalach każdej z tych grup wynosił $2,5 \%$ do $16 \%$. Analizując dynamikę zmian można zauważyć, że liczba mieszkań indywidualnych oraz przeznaczonych na sprzedaż z roku na rok zwiększa się, natomiast liczba mieszkań spółdzielczych oraz pozostałych charakteryzuje się w większości ujemną dynamiką rys. 1 .

\footnotetext{
${ }^{7}$ L. Frąckiewicz (red), Polityka społeczna. Zarys wykładu wybranych problemów. Śląsk, Katowice 2002, s.91

${ }^{8}$ P.Lis, Polityka państwa w zakresie finansowania inwestycji mieszkaniowych, C.H. Beck Warszawa 2008, s.16

${ }^{9}$ www.stat.gov.pl
} 
Tabela 1. Liczba oraz struktura mieszkań oddanych do użytku w latach 2002-2013

\begin{tabular}{|c|c|c|c|c|c|c|}
\hline \multirow{13}{*}{ 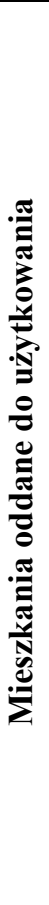 } & & Indywidualne & $\begin{array}{c}\text { Przeznaczone } \\
\text { na sprzedaż } \\
\text { lub wynajem }\end{array}$ & Spółdzielcze & Pozostałe & Ogółem \\
\hline & 2002 & 52433 & 21970 & 15406 & 7786 & 97595 \\
\hline & 2003 & 118034 & 23844 & 11957 & 8851 & 162686 \\
\hline & 2004 & 64858 & 24230 & 9432 & 9597 & 108117 \\
\hline & 2005 & 63279 & 33047 & 8222 & 9518 & 114066 \\
\hline & 2006 & 57594 & 37960 & 9032 & 10767 & 115353 \\
\hline & 2007 & 71259 & 46878 & 7881 & 7808 & 133826 \\
\hline & 2008 & 82633 & 67871 & 8687 & 6642 & 165833 \\
\hline & 2009 & 72211 & 72353 & 7373 & 8143 & 160079 \\
\hline & 2010 & 70425 & 53225 & 5146 & 6919 & 135715 \\
\hline & 2011 & 73034 & 50187 & 3834 & 4666 & 131721 \\
\hline & 2012 & 81244 & 63175 & 4085 & 4023 & 152527 \\
\hline & 2013 & 81147 & 57536 & 3511 & 3928 & 146122 \\
\hline
\end{tabular}

Źródto: opracowanie własne na podstawie danych GUS 2008, 2009a, 2010, 2011, 2012, 2013, 2014

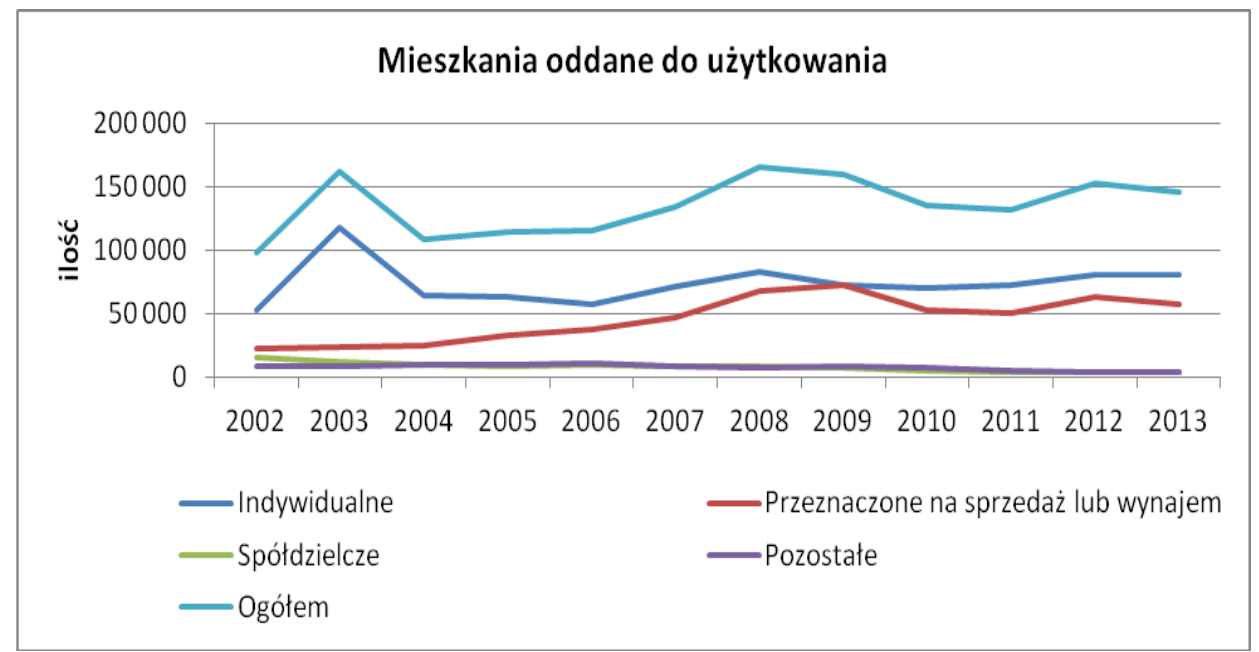

Rys. 1. Mieszkania oddane do użytkowania w latach 2007-2012

Źródto: opracowanie własne na podstawie danych GUS 2008, 2009a, 2010, 2011, 2012, 2013 
Aby określić podaż, również potencjalną lokali mieszkalnych, które mogą zasilić rynek należy, obok liczby mieszkań oddanych do użytku przeanalizować liczbę mieszkań których budowę rozpoczęto, a także wydane pozwolenia na budowę mieszkań. (rys. 2).

Począwszy od 2007 roku systematycznie maleje liczba wydawanych pozwoleń na budowę, co nie zawsze znacząco wpływa na liczbę mieszkań oddanych do użytku. Liczba mieszkań oddanych do użytkowania związana jest ściśle z liczbą mieszkań, których budowę rozpoczęto. Jeżeli dokona się opóźnienia jednej ze zmiennych, wówczas wartości obydwu zmiennych nakładają się na siebie. Oznacza to, że od momentu rozpoczęcia budowy mieszkań do momentu oddania ich do użytkowania mijają średnio dwa lata ${ }^{10}$.

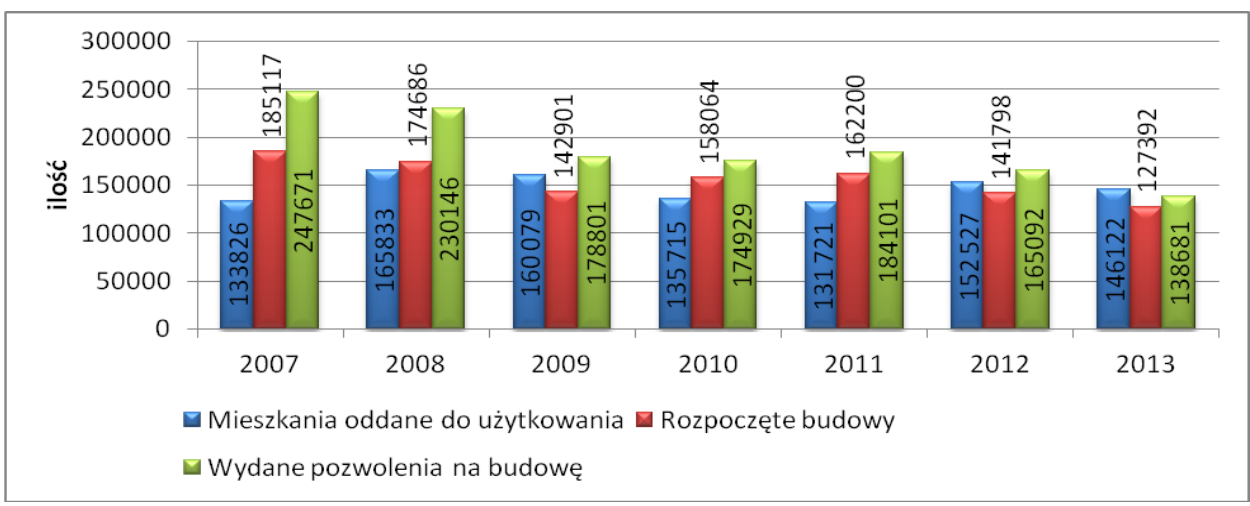

Rys.2. Ruch budowlany w latach 2007-2012 2014

Źródto: opracowanie własne na podstawie danych GUS 2008, 2009a, 2010, 2011, 2012, 2013,

Pod względem liczby oddawanych rocznie mieszkań do użytkowania Polska zajmuje piąte miejsce w Unii Europejskiej, jednak w przeliczeniu na liczbę mieszkańców jest to wciąż dosyć niski poziom. Wskaźnik liczby mieszkań oddanych do użytkowania w latach 2007 -2013 w przeliczeniu na 1000 mieszkańców kształtuje się na poziomie 3,5 - 4,5. Podobny poziom wskaźnika obserwuje się w większości krajów UE (wyższy w Irlandii i Hiszpanii, w latach 2005 - 2007 osiągał poziom 15-20 nowowybudowanych mieszkań na 1000 mieszkańców) ${ }^{11}$. Należy jednak odnieść wartość omawianego wskaźnika do zasobów mieszkaniowych poszczególnych krajów, uwzględniając jednocześnie liczbę mieszkańców. Wielkość zasobów mieszkaniowych może być oceniona i porównana za pomocą wskaźnika obrazującego liczbę mieszkań przypadającą na 1000 mieszkańców. Na tle krajów Unii Europejskiej Polska z wartością wskaźnika wynosząca 349 mieszkań na 1000 mieszkańców zajmuje jedno z ostatnich miejsc w Unii Europejskiej. Dla

\footnotetext{
${ }^{10} \mathrm{http}: / /$ www.dom.pl/64047-sredni-czas-budowy-mieszkan-i-domow-w-polsce.html, dostęp 20.02.2014 r.

${ }^{11}$ Strzeszyński J., Polski rynek mieszkaniowy. Analiza porównawcza największych miast, Instytut Analiz Monitor Rynku Nieruchomości mrn.pl, 2011, s. 1-8
} 
porównania, w 2008 roku w Hiszpanii wskaźnik ten wynosił 544, w Danii 500, w Finlandii 531, w Estonii $485^{12}$.

\section{GOSPODARSTWA \\ DOMOWE \\ W \\ PROGNOZACH \\ DEMOGRAFICZNYCH}

Wysokość deficytu mieszkaniowego na rynku szacowana była na podstawie prognoz Głównego Urzędu Statystycznego, określających liczbę gospodarstw domowych, stanowiących potencjalnych nabywców mieszkań na rynku. Główny Urząd Statystyczny przedstawił dwie prognozy dotyczące liczby gospodarstw domowych w Polsce. Pierwsza z nich obejmowała lata 2003-2030, i zakładała, że w 2015 roku w Polsce będzie blisko 15 mln gospodarstw domowych. Kolejna prognoza GUS na lata 2008-2035 przedstawiała wartości znacząco niższe niż poprzednia. Różnice $\mathrm{w}$ prognozach wynikały $\mathrm{z}$ faktu przystąpienia Polski do Unii Europejskiej, systematycznym otwieraniem granic i rynków pracy państw członkowskich i znacznym rozmiarem emigracji. Według szacunków GUS w 2007 roku liczba mieszkańców Polski przebywających czasowo za granicą (osoby, które nie dokonały wymeldowania $\mathrm{z}$ pobytu stałego w Polsce) osiągnęła najwyższą wartość szacowaną na 2270 tys $^{13}$. Przyczyną zmiany prognozy dotyczącej liczby gospodarstw w Polsce, oprócz faktu, że wielu młodych ludzi emigruje za granicę i tam zakłada gospodarstwo domowe jest przyrost naturalny na bardzo niskim poziomie (pod koniec 2012 r. wyniósł 0,01 \%). Różnica w liczbie gospodarstw domowych pomiędzy dwiema prognozami w roku 2012 wyniosła 190 tysięcy, a w roku 2013 niemal 230 tysięcy (tab. 2).

Tabela 2. Liczba gospodarstw domowych według prognoz GUS

\begin{tabular}{|c|c|c|c|c|c|}
\hline Rok & $\begin{array}{c}\text { Liczba gospodarstw } \\
\text { domowych w Polsce } \\
\text { (w tys., prognozy } \\
\text { GUS 2003-2030) }\end{array}$ & $\begin{array}{c}\text { Zmiana } \\
\text { (w tys.) }\end{array}$ & $\begin{array}{c}\text { Liczba } \\
\text { gospodarstw } \\
\text { domowych w } \\
\text { Polsce (w tys., } \\
\text { prognozy GUS } \\
\mathbf{2 0 0 8 - 2 0 3 5})\end{array}$ & $\begin{array}{c}\text { Zmiana } \\
\text { (w tys.) }\end{array}$ & $\begin{array}{c}\text { Różnica } \\
\text { między } \\
\text { prognozami } \\
\text { (w tys.) }\end{array}$ \\
\hline 2007 & 14164 & - & - & - & - \\
\hline 2008 & 14318 & 154 & 14277 & - & 42 \\
\hline 2009 & 14465 & 147 & 14388 & 112 & 77 \\
\hline 2010 & 14600 & 135 & 14487 & 98 & 113 \\
\hline 2011 & 14723 & 123 & 14571 & 84 & 152 \\
\hline 2012 & 14831 & 108 & 14641 & 70 & 190 \\
\hline 2013 & 14926 & 95 & 14697 & 57 & 229 \\
\hline
\end{tabular}

Źródło: opracowanie własne na podstawie danych GUS 2004, 2009b

\footnotetext{
${ }^{12}$ M. Cesarski, Polityka mieszkaniowa w Polsce w pracach naukowych 1918-2010: dokonania i wpływ polskiej szkoły badań, Oficyna Wydawnicza Szkoły Głównej Handlowej, Warszawa 2013, s. 205-219

${ }^{13}$ www. stat.gov.pl, Departament Badań Demograficznych,
} 
Obydwie prognozy zakładały systematyczny wzrost liczby gospodarstw domowych, aczkolwiek ze zmniejszającą się dynamiką wzrostu wraz z upływem czasu. Na podstawie prognoz liczby gospodarstw domowych i liczby mieszkań i założenia, że każde gospodarstwo domowe powinno posiadać jedno mieszkanie, statystyczny deficyt mieszkaniowy na koniec 2012 roku wynosił blisko $1 \mathrm{mln}$ lokali (tab.3).

Tabela 3. Szacowany deficyt mieszkaniowy w Polsce w latach 2007-2012

\begin{tabular}{|c|c|c|c|c|c|c|}
\hline Rok & $\begin{array}{c}\text { Liczba gospodarstw } \\
\text { domowych (wg. } \\
\text { prognozy GUS 2008- } \\
\text { 2035) }\end{array}$ & $\begin{array}{c}\text { Mieszkania } \\
\text { oddane do } \\
\text { użytkowania } \\
\text { mieszkań }\end{array}$ & $\begin{array}{c}\text { Ubytki } \\
\text { Szacowane } \\
\text { ubytki }\end{array}$ & $\begin{array}{c}\text { Liczba } \\
\text { mieszkań }\end{array}$ & $\begin{array}{c}\text { Deficyt } \\
\text { mieszkań }\end{array}$ \\
\hline 2007 & 14164000 & 133826 & 3044 & & 12993716 & 1170284 \\
\hline 2008 & 14276500 & 165833 & 2884 & & 13150294 & 1126206 \\
\hline 2009 & 14388300 & 160079 & 2999 & & 13302449 & 1085851 \\
\hline 2010 & 14486700 & 135715 & 3411 & & 13422011 & 1064689 \\
\hline 2011 & 14571100 & 131721 & 2778 & & 13550954 & 1020146 \\
\hline 2012 & 14640600 & 152527 & & 3023 & 13700458 & 940142 \\
\hline
\end{tabular}
2013

Źródlo: opracowanie własne na podstawie danych GUS 2008, 2009a, 2009b, 2010, 2011, 2012,

Według najnowszych danych z Narodowego Spisu Powszechnego przeprowadzonego w 2011 roku, które GUS udostępnił 29 stycznia 2013 roku, okazuje się, że prognozy dotyczące wzrostu liczby gospodarstw domowych były zbyt optymistyczne. W Polsce, na koniec marca 2011 roku funkcjonowało 13572 tys. gospodarstw domowych. To o prawie 1 mln mniej, niż jeszcze rok wcześniej było prognozowane. Wynikać to może ze zmian w metodyce liczenia i podawania stanu ludności do porównań międzynarodowych, wynikających z Rozporządzenia PE i Rady Nr 763/2008 z dnia 9 lipca 2008 r. w sprawie spisów powszechnych ludności i mieszkań. Począwszy od danych za 2011 rok corocznie, w najbliższych kilku latach będą upowszechniane dwa stany ludności: rezydująca i faktyczna. To ludność rezydująca jest obowiązującą w porównaniach międzynarodowych. Kategoria ludności rezydującej obejmuje bowiem stałych mieszkańców, z wyjątkiem osób przebywających poza miejscem zamieszkania przez okres co najmniej 12 miesięcy, bez względu na miejsce przebywania w kraju czy za granicą, a także osoby przebywające czasowo przez okres co najmniej 12 miesięcy, przybyłe z innego miejsca w kraju lub z zagranicy. Są więc to osoby, które przez rok lub dłużej związane są z konkretnym miejscem, a więc prawdopodobne jest, że osiedlą się w nim na dłużej. Z punktu widzenia planowania i polityki rozwoju, w tym rynku mieszkaniowego ta kategoria ludności jest bardziej istotna niż kategoria ludności faktycznej ponieważ kreuje popyt na rozmaite dobra i usługi. Zważywszy na ujemne saldo migracji w Polsce zmienia to całkowicie kwestię statystycznego deficytu mieszkań w Polsce. Według danych GUS na koniec marca 2011 roku liczba ludności faktycznie zamieszkałej wyniosła 38511 tys. osób i tworzyła 13568 tys. gospodarstw domowych (GUS, 2013). Jak podaje Śleszyński (2012) 
liczba ludności rezydującej w Polsce jest niższa i wynosi 37244 tys. osób. ${ }^{14}$ Zakładając, że gospodarstwa domowe tworzy 99,4\% ludności kraju (założenie GUS) oraz, że średnia liczba osób przypadających na jedno gospodarstwo domowe to 2,82 , obliczono liczbę gospodarstw domowych na poziomie 13127,8 tys. Stan zasobów mieszkaniowych na koniec 2011 roku to 13550954 mieszkań. W związku z powyższym, na koniec 2011 roku mieliśmy do czynienia $\mathrm{z}$ końcem statystycznego deficytu mieszkaniowego a nawet niewielką nadwyżką mieszkań w stosunku do liczby gospodarstw domowych. Nie oznacza to jednak końca problemów mieszkaniowych w Polsce. Kategoria statystycznego deficytu mieszkaniowego nie uwzględnia mieszkań niezamieszkałych przez osobę zameldowaną. Wśród tych mieszkań znajdują się lokale przeznaczone na sprzedaż lub wynajem, które w rzeczywistości zwiększają ogólną podaż mieszkań, zmniejszając tym samym zapotrzebowanie na wybudowanie nowych.

\section{JAKOŚĆ SUBSTANCJI MIESZKANIOWEJ}

Ważna kwestią pozostaje jakość zasobów mieszkaniowych (rys. 3). W Polsce co piąty lokal pochodzi $\mathrm{z}$ czasów przedwojennych, a ponad połowa istniejących zasobów mieszkaniowych została wybudowana w latach 1945-1988, z czego znaczny odsetek przypada na mieszkania z tzw. „wielkiej płyty”. Charakteryzują się one wysokimi kosztami eksploatacji, remontów, a także niskim komfortem akustycznym i brakiem garaży podziemnych. Mieszkań nowych, niewymagających nakładów remontowych, wybudowanych po 1989 roku jest blisko $25 \%$.

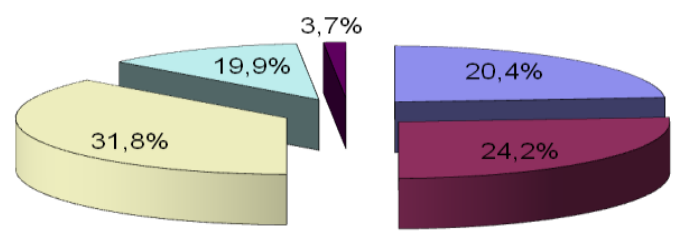

\begin{tabular}{|c|c|c|c|c|}
\hline 口Przed 1945 & 口1945- 1970 & ㅁ1971- 1988 & ㅁ1989- 2008 & -Wbudowie \\
\hline
\end{tabular}

Rys. 3 Struktura wiekowa mieszkań w Polsce

Źródło: opracowanie własne na podstawie danych GUS, $2012^{15}$

$\mathrm{Na}$ stosunkowo zły stan jakościowy zasobów mieszkaniowych w Polsce wskazuje również wskaźnik poważnej deprywacji mieszkaniowej, którym posługuje się statystyka Unii Europejskiej. Wskaźnik definiuje się jako odsetek osób zajmujących mieszkania uważane za przeludnione, w których dodatkowo występuje co najmniej jeden $\mathrm{z}$

\footnotetext{
${ }^{14}$ http://biuletynmigracyjny.uw.edu.pl/37-sierpien-2012/\%E2\%80\%9Efaktyczne\%E2\%80\%9Ddane-rzeczywiste-czyli-o-nsp-2011, dostęp 10.03.2014r.

${ }^{15}$ www.stat.gov.pl/cps/rde/xbcr/gus/lud_raport_z_wynikow_NSP2011.pdf, dostęp 20.03.2014r.
} 
wymienionych wyróżników, takich jak brak łazienki lub toalety, nieszczelny dach lub niedoświetlenie mieszkania. W 2011 r. w krajach Unii Europejskiej z poważną deprywacją mieszkaniową borykało się około 5,1\% ludności. W pięciu państwach członkowskich UE w warunkach poważnej deprywacji mieszkaniowej żyła więcej niż jedna dziesiąta obywateli, na Łotwie było to 16,4 \% mieszkańców, zaś w Rumunii aż 22,8 \%, a więc blisko jedna czwarta ludności. W odróżnieniu od tych państw, w Finlandii, Irlandii, Belgii i Holandii problem poważnej deprywacji mieszkaniowej dotyczył mniej niż $1 \%$ populacji (rys.4). W Polsce wskaźnik poważnej deprywacji dotyczy 11,4\% ludności, dla porównania w 2005 roku było to 29,7\% społeczeństwa.

Rys. 4 Wskaźnik poważnej deprywacji mieszkaniowej w krajach Unii Europejskiej w 2012 r.

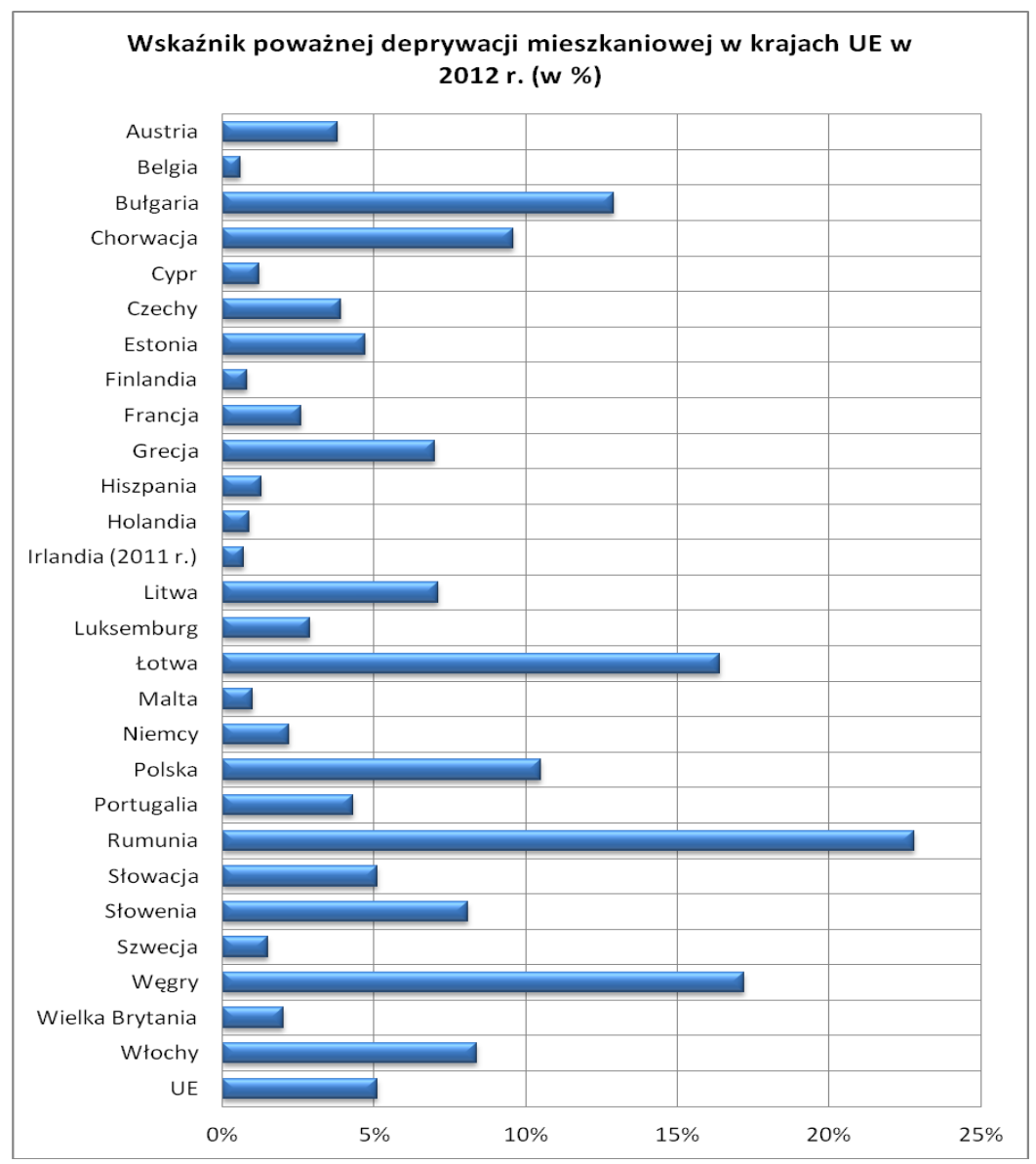

Źródło: opracowanie na podstawie danych Eurostat, $2014^{16}$

\footnotetext{
${ }^{16}$ http://epp.eurostat.ec.europa.eu/statistics_explained/index.php?title=File:Severe_housing_deprivat ion,_2011-12, dostęp: 10.05.2014r
} 
Analiza sytuacji mieszkaniowej w Polsce zwraca uwagę na problem niedostatecznej dostępności mieszkań. Przyczyną tej sytuacji jest nie tyle brak oferty, co przede wszystkim brak odpowiednich zasobów finansowych. Aby określić, czy gospodarstwa domowe mogą sobie pozwolić na zakup mieszkania należy porównać przeciętne wynagrodzenie brutto oraz cenę $1 \mathrm{~m}^{2}$ powierzchni użytkowej (p.u.) budynku mieszkalnego oddanego do użytkowania (rys. 5).

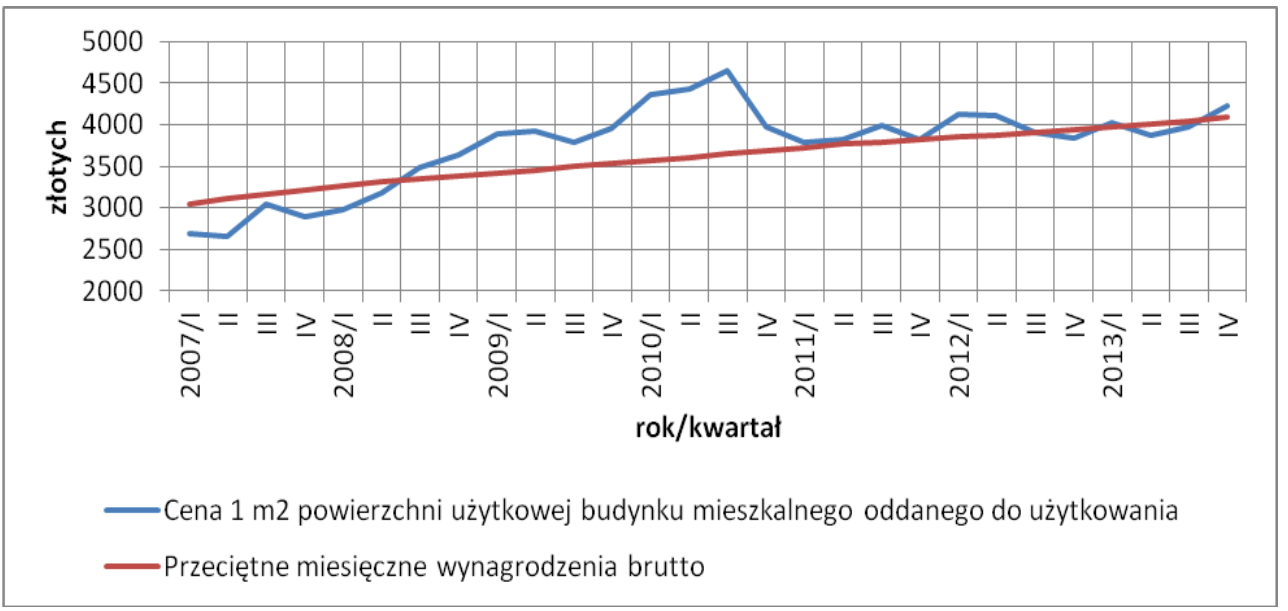

Rys. 5. Relacja średniej ceny $1 \mathrm{~m}^{2}$ powierzchni użytkowej budynku mieszkalnego oddanego do użytkowania w stosunku do przeciętnego wynagrodzenia brutto

Źródło: opracowanie własne na podstawie ${ }^{17}$

W badanych latach przeciętne wynagrodzenie brutto, jak i cena $1 \mathrm{~m}^{2}$ p.u. miały trend wzrostowy. Jednak przeciętne wynagrodzenie charakteryzuje się mniejszymi odchyleniami od wartości średnich niż druga z przedstawionych zmiennych. W badanym okresie jedynie w I, II i IV kwartale 2007 roku zauważa się, że przeciętne wynagrodzenie jest na wyższym poziomie niż przeciętna cena $1 \mathrm{~m}^{2}$ p.u. Od pierwszego kwartału roku 2008 do trzeciego kwartału roku 2010 cena $1 \mathrm{~m}^{2}$ powierzchni użytkowej budynku mieszkalnego była znacząco wyższa niż średnie wynagrodzenie. W III kwartale 2010 roku różnica pomiędzy zmiennymi wynosiła aż 1242 zł. Do końca badanego okresu cena za $1 \mathrm{~m}^{2}$ p.u. jest na zbliżonym poziomie $\mathrm{z}$ przeciętnym miesięcznym wynagrodzeniem. Ogranicza to zdolność kredytową i nabycie mieszkania przez przeciętnie zarabiającą część społeczeństwa.

\section{PODSUMOWANIE}

Sytuacja mieszkaniowa w Polsce jest wynikiem wielu czynników wpływających na rynek nieruchomości mieszkaniowych, głównie ekonomicznych i demograficznych. Rozpatrując dane statystyczne dotyczące efektów budowlanych w latach 2002-2013, jak

\footnotetext{
${ }^{17}$ www.stat.gov.pl/gus/5840_4671_PLK_HTML.htm, www.wynagrodzenia.pl/gus_kwartalne.php, dostęp: 20.03.2014r.
} 
również dane dotyczące liczby gospodarstw domowych nasuwa się wniosek o nieistnieniu w Polsce deficytu mieszkaniowego. Nie oznacza to jednak braku problemu mieszkaniowego. Statystyczna nadwyżka mieszkań w kraju jest wypadkową sytuacji na lokalnych rynkach nieruchomości mieszkaniowych. Problemem pozostaje natomiast zapewnienie mieszkań gospodarstwom domowych o średnich i niskich dochodach, których zarobki uniemożliwiają osiągnięcie zdolności kredytowej i zakup mieszkania. Bez pomocy publicznej nie są $\mathrm{w}$ stanie samodzielnie zrealizować swoich potrzeb mieszkaniowych. W ramach prowadzonej polityki mieszkaniowej wspieranie tych gospodarstw domowych w uzyskaniu (lub zapewnieniu) mieszkania spoczywa głównie na gminach. Jednakże kierowana pomoc publiczna jest wciąż niewystarczająca, stąd wynika zbyt mały udział budownictwa społecznego czynszowego oraz spółdzielczego lokatorskiego przeznaczonego dla gospodarstw domowych o średnim poziomie dochodów. Brakuje również mieszkań socjalnych. Z cyklicznie przeprowadzanych audytów Najwyższej Izby Kontroli wynika, że w wielu gminach czas oczekiwania na lokal socjalny wynosi kilka lat. Brak odpowiedniego poziomu środków finansowych na gospodarkę mieszkaniową gmin skutkuje również pogorszeniem stanu technicznego i obniżeniem wartości użytkowej najstarszej części zasobu mieszkaniowego, której właścicielami są głównie samorządy gminne. Pomoc publiczna kierowana jest głównie do ludzi młodych, jednakże postępujące zmiany demograficzne związane ze starzeniem się społeczeństwa będą skutkowały wnikliwemu przyjrzeniu się sytuacji mieszkaniowej nie tylko ludzi młodych, wkraczających na rynek pracy, ale również tych, którzy z tego rynku ustępują.

\section{LITERATURA}

[1] Andrzejewski A., Polityka mieszkaniowa, PWE Warszawa 1987, s. 28-31

[2] Cesarski M., Polityka mieszkaniowa w Polsce w pracach naukowych 19182010: dokonania i wpływ polskiej szkoły badań, Oficyna Wydawnicza Szkoły Głównej Handlowej, Warszawa 2013, s. 205-219

[3] Frąckiewicz L. (red), Polityka społeczna. Zarys wykładu wybranych problemów, Śląsk, Katowice 2002, s.91

[4] Główne problemy, cele $i$ kierunki programu wspierania rozwoju budownictwa mieszkaniowego do 2020 roku

[5] Hut P., Współczesna kwestia mieszkaniowa w Polsce; geneza, uwarunkowania, perspektywy rozwiazań W: Polityka spoleczna (red) G. Firlit-Fesnak i M. Szylko-Skoczny, Wydawnictwo Naukowe PWN Warszawa 2009, s. 294

[6] Lis P., Polityka państwa $w$ zakresie finansowania inwestycji mieszkaniowych, C.H. Beck Warszawa 2008, s.16

[7] Strzeszyński J., Polski rynek mieszkaniowy. Analiza porównawcza największych miast, Instytut Analiz Monitor Rynku Nieruchomości mrn.pl, 2011, s. $1-8$

[8] Śleszyński P., http://biuletynmigracyjny.uw.edu.pl/37-sierpień 2012/\%E2\%80\%9Efaktyczne\%E2\%80\%9D-dane-rzeczywiste-czyli-o-nsp2011

[9] http://appsso.eurostat.ec.europa.eu/nui/show.do?dataset=ilc_mdho06a\&lang $=$ en). 
[10] http://www.stat.gov.pl/cps/rde/xbcr/gus/lud_raport_z_wynikow_NSP2011.p df

\section{HOUSING SITUATION IN POLAND DURING 2007-2013 IN THE CONTEXT} OF DEMOGRAPHIC CHANGE

Home is as an example of essential goods, and the accessibility of housing is a necessary condition for the proper functioning and development of a family (a household). Questions such as the ownership, availability and quality of housing resources are in the focus of housing policy. Housing policy consists of all actions pursued by the state that have impact on the operations and outcome of the housing market, i.e. number of apartments, prices, rents and quality of housing space. The housing resources in Poland are estimated to comprise 13747 thousand apartments (Main Statistical Office 2013). For an assessment of the national housing resources, an index of the number of apartments per 1000 residents was used. In Poland, this index equals 349, and is therefore among the lowest in the European Union. The government document, published in 2010 under the title 'Main problems, aims and directions of the programme of support to the residential construction industry until 2020 ',defines the deficit of housing resources as the difference between the number of households and the number of occupied apartments, which in Poland equals $1.4-1.5$ million of apartments. These estimates are based on data from the National Census of 2002 and statistical predictions on the number of households. At the same time, over 1.6 new apartments were built between 2002 and 2013. The housing deficit is affected by the demographic factors, especially migration in search of employment. The aim of this paper has been to analyze the housing situation and the demand for housing in the light of the changing demographic situation in Poland. The evaluation was based on statistical data (the National Census) of 2011, including demographic changes in 2002-2013.

Keywords: apartment, housing situation, housing demand, housing policy, housing deficit.

DOI:10.7862/rz.2016.hss.45

Przesłano do redakcji: grudzień 2014

Przyjęto do druku: wrzesień 2016 